\title{
PARA ONDE VÃO OS NOSSOS SENTIDOS?
}

\section{WHAT HAS HAPPENED TO OUR PERCEPTIONS?}

\section{Armando de Oliveira e Silva, TCBC}

Até que ponto o avanço tecnológico está interferindo com a relação médico-paciente?

Até que ponto o médico está se submetendo à tecnologia, perdendo um fator importante da relação que é o contato direto com os problemas que afligem o doente?

Entendemos que a modernidade da tecnologia, aplicada de forma racional e usada de acordo com as necessidades reais, traz, sem dúvida, vantagens no esclarecimento de um diagnóstico.

A tecnologia, ao atualizar-se, incorpora procedimentos cada vez mais sofisticados, a maioria invasivos e dependentes de equipamentos de alto investimento.

Isto exige retorno.

Isto obriga o seu uso de forma mais abrangente, com a criação de novas normas para sua maior utilização. Novas rotinas são, então, implantadas, procurando-se em alguns casos criar novos caminhos para a definição de um diagnóstico.

Não concordamos com esta obrigatoriedade, por não acharmos que a justificativa de que o método faz parte de um programa ou protocolo seja suficiente para que o usemos de forma indiscriminada.

Não acreditamos que o médico tenha perdido a capacidade de usar os seus sentidos tão bem treinados para analisar informações colhidas de um corpo doente e necessitado. A capacidade de ouvir queixas, observar lesões, sentir odores, auscultar ruídos e palpar ou percutir segmentos do corpo humano foram e continuam a ser a forma clássica com que iniciamos uma avaliação médica.

Não devemos queimar etapas e iniciar a investigação utilizando imediatamente uma máquina para nos substituir.

Apenas com os seus sentidos o médico devidamente treinado é capaz de suspeitar e até mesmo identificar um número expressivo de doenças.

Não queremos ser apologistas da não aceitação de novos métodos que nos auxiliem na elucidação de um diagnóstico. Defendemos o seu uso no momento apropriado, de acordo com a sequência natural de uma avaliação. Não concordamos, isto sim, é com o seu uso indiscriminado. Não aceitamos a substituição do homem que pensa, pela máquina fria, simplesmente pelo fato de haver um protocolo a ser seguido.

O diagnóstico de algumas afecções cirúrgicas como a apendicite, a colecistite e a úlcera péptica perfurada, quando exteriorizadas de forma clássica, necessitam apenas de confirmação através de um hemograma, uma ultrassonografia ou uma rotina radiológica simples de abdome.

Não entendemos o uso de exames mais complexos sendo antecipados e usados de forma prioritária. Entendemos plenamente o seu uso nesses mesmos casos quando, por apresentarem manifestações atípicas, não se tenha conseguido dar uma orientação precisa e adequada.

A pressão exercida sobre o médico, forçando-o a seguir algoritmos pré determinados, afronta e cria um vício de conduta que faz com que as normas básicas da relação médico-paciente sejam substituídas por túneis claustrofóbicos, manejados por terceiros, envolvidos com botões e tabelas estereotipadas para serem usadas de forma programada.

Não me agrada esta substituição. Creio que o médico deva saber avaliar as vantagens e as desvantagens da máquina, usando-a quando houver certeza da sua necessidade e que o seu uso, realmente, seja capaz de determinar resultados claros e efetivos. 